\title{
Pertumbuhan dan Hasil Tanaman Bawang Merah (Allium ascalonicum L.) pada Pemberian Berbagai Dosis Pupuk Kandang Kotoran Sapi dan PGPR Akar Bambu
}

\author{
(Growth and Yield of Shallot (Allium ascalonicum L.) on Various Doses of \\ Cow Manure and Bamboo Root PGPR)
}

\author{
Mahdiannoor*), Murjani \& Isma \\ Program Studi Agroteknologi, Sekolah Tinggi Ilmu Pertanian Amuntai \\ ${ }^{*}$ mahdi_186@yahoo.com
}

\begin{abstract}
ABSTRAK
Bawang merah merupakan komoditas penting yang menjadi kebutuhan pangan pokok masyarakat Indonesia. Petani umumnya menggunakan pupuk kimia atau anorganik dalam kegiatan budidayanya. Pupuk anorganik mampu mempercepat masa tanam karena unsur haranya mampu diserap langsung oleh tanah. Namun, penggunaan pupuk anorganik yang terus menerus dapat mengakibatkan dampak negatif bagi tanah dan lingkungan, maka untuk menghindarinya yaitu dengan beralih menggunakan pupuk organik. Pupuk kandang merupakan salah satu pupuk organik yang dapat menambah tersedianya unsur hara bagi tanaman. Dengan adanya bakteri yang intensif, maka dapat mempercepat tersedianya unsur hara. Bakteri yang berperan untuk menguraikan bahan organik disebut PGPR. Penelitian ini bertujuan untuk (i) Mengetahui interaksi (ii) mengetahui faktor tunggal pupuk kandang kotoran sapi (iii) mengetahui faktor tunggal PGPR akar bambu (iv) mendapatkan interaksi terbaik (v) mendapatkan dosis terbaik pupuk kandang kotoran sapi (vi) mengetahui dosis terbaik PGPR akar bambu. Penelitian dilaksanakan di lahan alluvial di Kabupaten Tabalong dari bulan Maret-Juni 2019. Penelitian ini menggunakan Rancangan Acak Kelompok Faktorial dengan perlakuan adalah dosis pupuk kandang kotoran sapi yaitu: $p_{1}=10 \mathrm{t} / \mathrm{ha}, p_{2}=20 \mathrm{t} / \mathrm{ha}$ dan $p_{3}=30 \mathrm{t} / \mathrm{ha}$, sedangkan PGPR akar bambu yaitu: $b_{1}=20 \mathrm{ml}, b_{2}=25 \mathrm{ml}$ dan $b_{3}=30 \mathrm{ml}$, jadi kombinasnya adalah 9 perlakuan. Hasil penelitian menunjukan bahwa pada variabel pengamatan tinggi tanaman, jumlah daun, jumlah umbi, diameter umbi dan berat umbi hanya berpengaruh pada tinggi tanaman dengan perlakuan faktor tunggal pupuk kandang kotoran sapi dan dosis terbaik adalah 20 t/ha.
\end{abstract}

Kata kunci : Dosis, pupuk kandang, PGPR, bawang merah.

\begin{abstract}
Shallot is an important commodity that becomes the basic food needs of the Indonesian people. Farmers generally use chemical or inorganic fertilizers in their cultivation activities. Inorganic fertilizers can accelerate the growing period because the nutrients can be absorbed directly by the soil. However, the continuous use of inorganic fertilizers can harm the soil and the environment, then to avoid this is to switch to using organic fertilizers. Manure is one of the organic fertilizers that can increase the availability of nutrients for plants. With the presence of intensive bacteria, it can accelerate the availability of nutrients. Bacteria whose role is to decompose organic matter are called PGPR. This study aims to (i) know the interactions (ii) know the single factor of cow manure (iii) know the single factor of bamboo root PGPR (iv) get the best interaction (v) get the best dose of cow manure (vi) get the best dose of bamboo root PGPR. This research was carried out in alluvial land in Tabalong District from MarchJune 2019. This study used a factorial randomized block design with the treatment is a dose of cow manure, namely: $p_{1}=10 \mathrm{t} / \mathrm{ha}, p_{2}=20 \mathrm{t} / \mathrm{ha}, p_{3}=30 \mathrm{t} / \mathrm{ha}$, while the bamboo roots PGPR are: $b_{1}=20 \mathrm{ml}$, $b_{2}=25 \mathrm{ml}$, and $b_{3}=30 \mathrm{ml}$, so the combination is 9 treatments. The results showed that the observed variables were plant height, number of leaves, number of tubers, tuber diameter and tuber weight only affected plant height with a single factor treatment of cow manure and the best dose was $20 \mathrm{t} / \mathrm{ha}$.
\end{abstract}

Keywords: Dosage, manure, PGPR, shallot.

PENDAHULUAN
Bawang merah merupakan komoditas penting yang menjadi kebutuhan 
pangan pokok masyarakat Indonesia. Di Kabupaten Tabalong Provinsi Kalimantan Selatan untuk kegiatan budidaya bawang merah tergolong baru yaitu sejak tahun 2013 (Lasmiati, 2013).

Produksi bawang merah di Kabupaten Tabalong pada tahun 2015 yaitu $40 \mathrm{kw}$ dengan luas panen 4 ha dan rata-rata produksi $10 \mathrm{kw} / \mathrm{ha}$, pada tahun 2016 adalah $65 \mathrm{kw}$ dengan luas panen 10 ha dan rata-rata produksi 6,5 kw/ha, dan pada tahun 2017 adalah $49 \mathrm{kw}$ (BPS Kabupaten Tabalong, 2018). Data tersebut menunjukkan bahwa produksi bawang merah terus mengalami penurunan. Hal ini terjadi karena para petani umumnya menggunakan pupuk kimia atau anorganik dalam kegiatan budidayanya.

Pupuk anorganik mampu mempercepat masa tanam karena unsur haranya mampu diserap langsung oleh tanah dan mampu meningkatkan produksi tanaman. Namun, penggunaan pupuk anorganik yang terus menerus dapat mengakibatkan dampak negatif bagi tanah dan lingkungan (Susetya, 2012 dalam Januarti, et. al., 2016).

Pupuk kandang kotoran sapi merupakan pupuk pupuk dingin, yaitu pupuk yang perubahan-perubahannya berlangsung perlahan-lahan. Dengan adanya bakteri atau jasad renik yang intensif, maka dapat mempercepat terwujudnya perubahanperubahan itu atau tersedianya unsur hara dalam tanah bagi kepentingan tanaman (Sutedjo, 2008). Bakteri yang berperan untuk menguraikan bahan organik disebut PGPR.

\section{PGPR (Plant Prowth Promoting} Rhizobacteria) atau dalam bahasa Indonesia berarti bakteri perakaran pemacu pertumbuhan tanaman (BP3T) adalah bakteri yang terdapat di sekitar perakaran rumpun bambu dimana terdapat eksudat yang dikeluarkan akar sebagai nutrisi bagi mikroba. PGPR mengandung bakteri Pseudomonas flourenscens dan Bacillus polymixa yang mampu memacu pertumbuhan tanaman melalui beberapa cara, yaitu : merombak dan mengurai bahan organik menjadi nutrisi tanaman, mengeluarkan cairan yang mampu melarutkan mineral phosphate menjadi unsur hara, mengeluarkan enzim pemacu pertumbuhan tanaman, mengeluarkan antibiotik dan menekan mikroba patogen serta membantu menangkap dan mengumpulkan nitrogen (N) dari udara, selanjutnya diubah menjadi unsur yang siap diserap tanaman (Yuliandri, 2017).

Penelitian Sejati, et. al., (2017) tentang pengaruh macam pupuk kandang dan konsentrasi Pseudomonas fluorescens pada hasil tanaman bawang merah (Allium cepa fa. Ascalonicum, L.) Varietas Crok Kuning, menyatakan bahwa penambahan pupuk kandang mampu meningkatkan tinggi tanaman, jumlah daun, jumlah siung per rumpun, berat umbi segar per rumpun, berat umbi kering simpan per rumpun dan dan diameter siung per rumpun bawang merah. Semakin tinggi konsentrasi Pseudomonas fluorescens sampai $20 \mathrm{ml} / \mathrm{l}$ masih meningkatkan tinggi tanaman, jumlah daun, jumlah siung per rumpun, berat umbi segar per rumpun dan berat kering simpan per rumpun bawang merah.

Sehubungan dengan permasalahan tersebut agar menghasilkan pertumbuhan bawang merah dengan kualitas yang baik, maka perlu dilaksanakan penelitian pertumbuhan dan hasil tanaman bawang merah (Allium ascalonicum L.) pada pemberian berbagai dosis pupuk kandang kotoran sapi dan PGPR akar bambu.

\section{METODE PENELITIAN}

Penelitian ini dilaksanakan di Desa Banyu Tajun Kecamatan Tanjung Kabupaten Tabalong dari bulan Maret sampai Juni 2019. Menggunakan Rancangan Acak Kelommpok (RAK) faktorial dua faktor. Dengan pengelompokkan berdasarkan berat umbi. Faktor pertama yang diteliti adalah pupuk kandang kotoran sapi (P), terdiri dari 3 taraf yaitu: $\mathrm{p}_{1}=10 \mathrm{t} / \mathrm{ha}, \mathrm{p}_{2}=20 \mathrm{t} / \mathrm{ha}, \mathrm{p}_{3}=30 \mathrm{t} / \mathrm{ha}$. Faktor kedua adalah dosis PGPR akar bambu (B) terdiri dari 3 taraf yaitu: $\mathrm{b}_{1}=20$ $\mathrm{ml} /$ tanaman, $\mathrm{b}_{2}=25 \mathrm{ml} / \mathrm{tanaman}, \mathrm{b}_{3}=30$ $\mathrm{ml} /$ tanaman. Berdasarkan perlakuan yang akan dicoba maka didapat 9 kombinasi perlakuan dengan 3 kelompok maka di didapat 27 satuan percobaan. Setiap satuan 
percobaan terdiri dari 16 tanaman dengan 4 sampel yang diamati.

\section{HASIL DAN PEMBAHASAN}

\section{Hasil}

\section{Tinggi Tanaman (cm)}

Berdasarkan hasil analisis ragam antara pupuk kandang kotoran sapi dan dan Tabel 1. Hasil uji beda rata-rata tinggi tanaman bawang merah umur 23 dan 33 HST dengan pemberian pupuk kandang kotoran sapi.

\begin{tabular}{ccc}
\hline \multirow{2}{*}{ Perlakuan } & \multicolumn{2}{c}{ Rerata tinggi tanaman bawang merah $(\mathrm{cm})$} \\
\cline { 2 - 3 } & $23 \mathrm{HST}$ & $33 \mathrm{HST}$ \\
\hline $\mathrm{p}_{1}$ & $17.94^{\mathrm{a}}$ & $17.82^{\mathrm{a}}$ \\
$\mathrm{p}_{2}$ & $20.06^{\mathrm{b}}$ & $23.40^{\mathrm{b}}$ \\
$\mathrm{p}_{3}$ & $19.69^{\mathrm{b}}$ & $22.10^{\mathrm{b}}$ \\
\hline
\end{tabular}

Keterangan : angka yang diikuti huruf yang sama pada kolom yang sama tidak berbeda nyata berdasarkan uji DMRT pada taraf 5\%.

Dari tabel terlihat tinggi tanaman umur 23 perlakuan terbaik pada $\mathrm{p}_{2}$ yaitu $20,06 \mathrm{~cm}$ tidak berbeda dengan perlakuan $\mathrm{p}_{3}$ yaitu 19,69 $\mathrm{cm}$ dan berbeda dengan perlakuan $\mathrm{p}_{1}$ yaitu $19,69 \mathrm{~cm}$, sedangkan pada umur 33 HST perlakuan terbaik pada $\mathrm{p}_{2}$ yaitu $23,40 \mathrm{~cm}$ tidak berbeda dengan perlakuan $\mathrm{p}_{3}$ yaitu $22,10 \mathrm{~cm}$ dan berbeda dengan perlakuan $\mathrm{p}_{1}$ yaitu $17,82 \mathrm{~cm}$.
PGPR akar bambu pada pengamatan tinggi tanaman pada umur 23, 33 dan 43 HST tidak berpengaruh secara interaksi, namun pada perlakuan tunggal pupuk kandang kotoran sapi berpengaruh nyata pada umur 23 HST dan sangat nyata umur 33 HST, tetapi tidak berpengaruh pada umur $43 \mathrm{HST}$, hasil uji beda rata-rata umur 23 HST disajikan pada Tabel 1 sedangkan perlakuan tunggal PGPR akar bambu tidak berpengaruh.

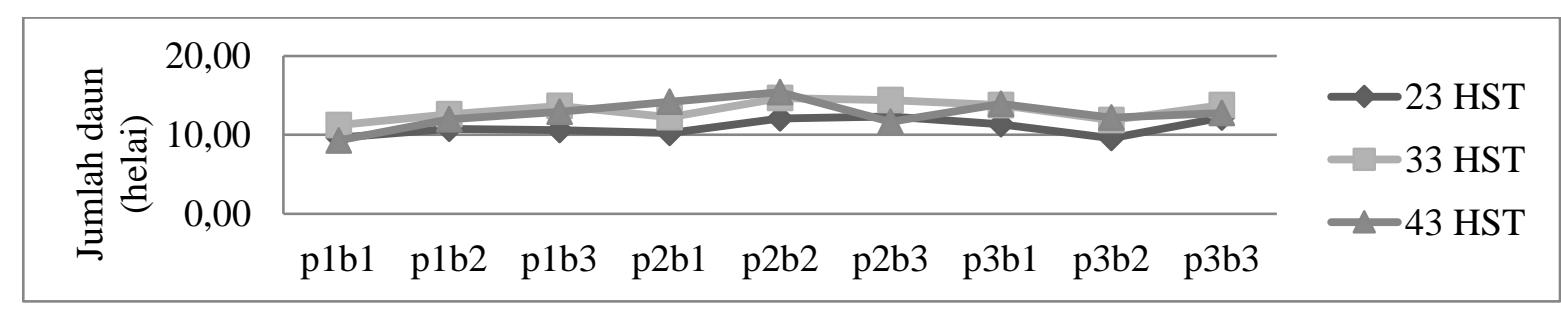

Gambar 1. Grafik hubungan interaksi pupuk kandang kotoran sapi dan PGPR akar bambu

terhadap jumlah daun tanaman bawang merah.

\section{Jumlah Daun (helai)}

Berdasarkan hasil analisis ragam antara pupuk kandang kotoran sapi dan dan PGPR akar bambu pada pengamatan jumlah daun tanaman pada umur 23 HST, 33 HST dan 43 HST tidak berpengaruh secara interaksi maupun perlakuan tunggal. Grafiknya dapat dilihat pada gambar 1 .

\section{Dari grafik terlihat bahwa semakin tinggi dosis pupuk kandang kotoran sapi dan PGPR akar bambu maka jumlah daun tanaman semakin meningkat, kecuali pada perlakuan $\mathrm{p}_{2} \mathrm{~b}_{3}, \quad \mathrm{p}_{3} \mathrm{~b}_{1}, \quad \mathrm{p}_{3} \mathrm{~b}_{2}$ dan $\mathrm{p}_{3} \mathrm{~b}_{3}$, peningkatan dosis pupuk kandang kotoran sapi dan PGPR akar bambu tidak mampu meningkatkan jumlah daun.}

\section{Jumlah Umbi}

Berdasarkan hasil analisis ragam antara pupuk kandang kotoran sapi dan PGPR akar bambu pada pengamatan jumlah umbi tanaman pada bawang merah tidak berpengaruh secara interaksi maupun perlakuan tunggal. Grafiknya dapat dilihat pada Gambar 2.

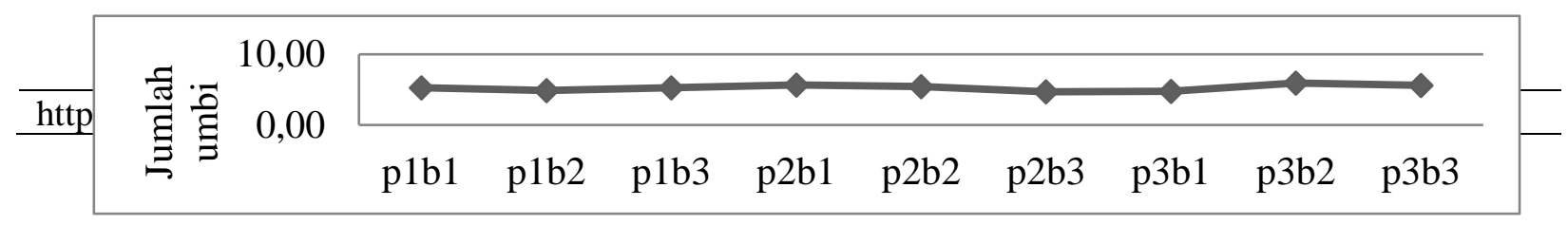


Gambar 2. Grafik hubungan interaksi pupuk kandang kotoran sapi dan PGPR akar bambu terhadap jumlah umbi tanaman bawang merah.

Dari grafik terlihat bahwa semakin tinggi dosis pupuk kandang kotoran sapi dan PGPR akar bambu maka jumlah umbi semakin meningkat, kecuali pada $\mathrm{p}_{3} \mathrm{~b}_{3}$ peningkatan dosis pupuk kandang kotoran sapi dan PGPR akar bambu tidak mampu meningkatkan jumlah umbi.

\section{Diameter Umbi (cm)}

Berdasarkan hasil analisis ragam antara pupuk kandang kotoran sapi dan dan PGPR akar bambu pada pengamatan diameter umbi tanaman bawang merah tidak berpengaruh secara interaksi maupun perlakuan tunggal. Grafiknya dapat dilihat pada gambar 3 .

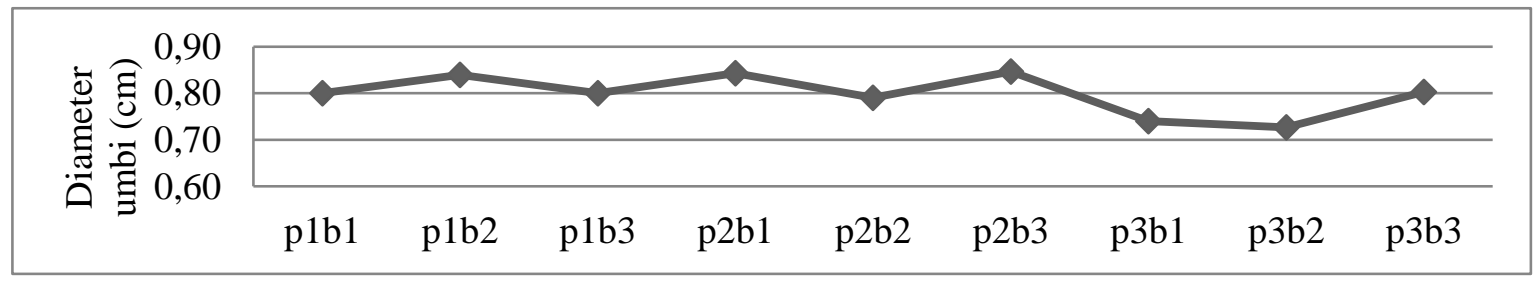

Gambar 3. Grafik hubungan interaksi pupuk kandang kotoran sapi dan PGPR akar bambu terhadap diameter tanaman bawang merah.

Dari grafik terlihat bahwa semakin tinggi dosis pupuk kandang kotoran sapi dan PGPR akar bambu maka diameter umbi semakin menurun.

\section{Berat umbi (g)}

Berdasarkan hasil analisis ragam antara pupuk kandang kotoran sapi dan dan PGPR akar bambu pada pengamatan berat umbi/tanaman tidak berpengaruh secara interaksi maupun perlakuan tunggal. Grafiknya dapat dilihat pada gambar 4.

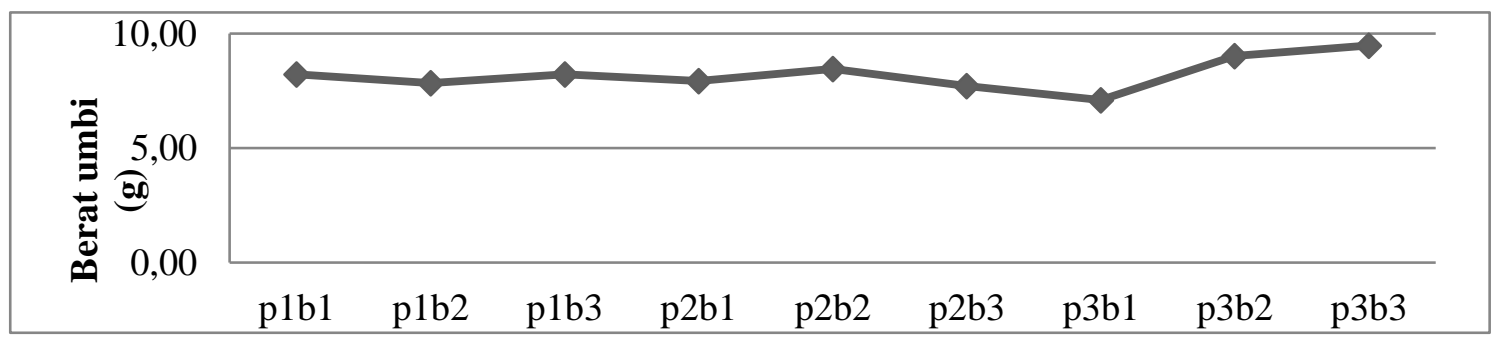

Gambar 4. Grafik hubungan interaksi pupuk kandang kotoran sapi dan PGPR akar bambu terhadap berat umbi/tanaman bawang merah.

Dari grafik terlihat bahwa semakin tinggi dosis pupuk kandang kotoran sapi dan PGPR akar bambu maka berat umbi semakin meningkat.

\section{Pembahasan}

Interaksi pupuk kandang kotoran sapi dan PGPR akar bambu
Berdasarkan hasil analisis ragam menunjukkan bahwa interaksi pupuk kandang kotoran sapi dan PGPR akar bambu tidak berpengaruh terhadap semua variabel pengamatan. Hal ini diduga dengan penambahan dosis pupuk kandang menyebabkan C-organik semakin tinggi dan penambahan PGPR menyebabkan $\mathrm{pH}$ tanah 
semakin masam, sehingga mikroorganisme yang terdapat pada PGPR tidak mampu merobaknya dengan baik.

Hasil analisis tanah menunjukkan bahwa tanah yang digunakan dalam penelitian termasuk sangat masam, terlihat dari $\mathrm{pH}$ tanah yaitu 3,80. Akan tetapi dilihat dari Kandungan C organik 1,196 (sedang), $\mathrm{N}$ total 0,252 (sedang) dan $\mathrm{P} \quad 4,152$ (sedang)dan K 0,075 (sangat rendah) dan $\mathrm{Fe}$ 29,685 (sangat tinggi).Hasil analisis pupuk kandang kotoran sapi alkalis atau basa terlihat dari $\mathrm{pH}$ yaitu dengan 9,36 dengan $\mathrm{C}$ organik 28,59 dan $\mathrm{N}$ total 1,649 yang termasuk sangat tinggi, sedangkan $\mathrm{P} 1,154$ dan K 3,932 sangat rendah. Hasil analisis PGPR yaitu pH 5,21 (masam), $\mathrm{N}$ 0,05 (sedang), $\mathrm{P}_{2} \mathrm{O}_{2} \quad 0,10$ dan $\mathrm{K}_{2} \mathrm{O} 0,05$ (sangat rendah).

$\mathrm{pH}$ tanah dapat mempengaruhi ketersediaan hara tanah dan bisa menjadi faktor yang berhubungan dengan kualitas tanah. pH sangat penting dalam menentukan aktivitas dan dominasi mikroorganisme tanah yang berhubungan dengan prosesproses yang sangat erat kaitannya dengan siklus hara (Sudaryono, 2009). Kebanyakan bakteri mempunyai $\mathrm{pH}$ optimum untuk pertumbuhan, yaitu $\mathrm{pH}$ 6,5-7,5. Pada $\mathrm{pH}$ dibawah 5 dan di atas 8,5, bakteri tidak dapat tumbuh dengan baik. (Waluyo, 2007 dalam Jannah, 2016).

Menurut Spur Way (1941) dalam Samadi dan Cahyono (2005) tanaman bawang merah akan tumbuh baik pada tanah dengan kisaran $\mathrm{pH}$ optimum 5,8-7,0, tetapi tanaman bawang merah masih toleran terhadap tanah dengan $\mathrm{pH}$ 5,5. Menurut Sudaryono (2009) pada pH kurang dari 5,5 ion fosfat akan diikat oleh Fe dan Al sebagai senyawa yang tidak larut dalam air, sedangkan diatas $\mathrm{pH} 7$ akan bereaksi dengan $\mathrm{Ca}$ dan $\mathrm{Mg}$ membentuk senyawa yang larut dalam air dan menjadi tidak tersedia bagi tanaman.

Faktor lain yang menjadi kendala adalah $\mathrm{Fe}$ yang sangat tinggi. Kelebihan $\mathrm{Fe}$ dalam tanah menyebabkan akar tanaman tidak dapat menyerap hara yang dibutuhkan, sehingga aktivitas tanaman terganggu (Prasojo, 2018). Penyerapan Fe yang sangat tinggi oleh akar tanaman mengakibatkan perkembangan akar tidak normal (Harianti, et. al., 2004). Sebagian besar unsur besi pada tanaman disimpan dalam kloroplast, sehingga kelebihan besi menyebabkan terpengaruhnya organel tersebut (Yadavalli et. al., 2012 dalam Nugraha dan Rumanti, 2017). Keracunan besi juga mengakibatkan menurunnya permeabilitas membran sel penjaga yang mengatur pembukaan stomata (Pareira, e,t. al., 2013 dalam Nugraha dan Rumanti, 2017). Keracunan Fe pada tanaman ini diperlihatkan dengan banyaknya serangan bercak cokelat, adanya noda-noda kecil berwarna cokelat pada daun (Kaderi, 2015).

Pada variabel pengamatan tinggi tanaman dan jumlah daun pada perlakuan dosis pupuk kandang kotoran sapi 10 t/ha dengan penambahan peningkatan dosis PGPR akar bambu menyebabkan tinggi tanaman semakin menurun, tetapi jumlah daun semakin meningkat, diduga pada dosis pupuk kandang tersebut tidak dapat memperbaiki $\mathrm{pH}$ dan penambahan PGPR akar bambu membuat tanah semakin masam. Selain itu, diduga unsur hara $\mathrm{N}$ yang digunakan untuk pertumbuhan tinggi tanaman dan jumlah daun tidak mencukupi, sehingga hanya bisa meningkatkan jumlah daun. $\mathrm{N}$ berfungsi untuk menyusun asam amino (protein), asam nukleat, nukleotida dan klorofil pada tanaman, sehingga membuat tanaman lebih hijau, mempercepat pertumbuhan tanaman (tinggi, jumlah anakan, jumlah cabang dan menambah protein hasil panen (Rina, 2019).

Pada perlakuan pupuk kadang kotoran sapi dosis 20 t/ha dengan penambahan peningkatan dosis PGPR akar bambu mampu meningkatkan tinggi tanaman dan jumlah daun, diduga karena pada dosis pupuk kandang tersebut dapat memperbaiki $\mathrm{pH}$. Sedangkan pada pupuk kandang kotoran sapi dosis 30 t/ha dengan peningkatan dosis PGPR hasilnya tidak berbeda, diduga karena pupuk kandang belum terdekomposisi dengan sempurna.

Pada variabel pengamatan jumlah umbi dan diameter umbi perlakuan pupuk kandang kotoran sapi dosis 10 dan 20 t/ha dengan penambahan peningkatan dosis 
PGPR akar bambu tidak meningkatkan jumlah umbi, hal ini diduga karena pada dosis pupuk kandang tersebut tidak dapat memperbaiki $\mathrm{pH}$ tanah. Sedangkan pada perlakuan pupuk kandang dosis 30 t/ha dengan penambahan peningakatan dosis PGPR akar bambu sampai dosis 25 $\mathrm{ml} /$ tanaman mampu meningkatkan jumlah umbi, tetapi diameternya menurun, hal ini diduga karena pada dosis pupuk kandang tersebut mampu memperbaiki $\mathrm{pH}$ tetapi masih kekurangan unsur $\mathrm{K}$, sehingga meningkatnya jumlah umbi menyebabkan diameternya menurun. Pada jumlah umbi yang lebih banyak memerlukan unsur $\mathrm{K}$ yang lebih banyak. Kalium merupakan unsur ketiga setelah $\mathrm{N}$ dan $\mathrm{P}$ yang dibutuhkan tanaman dalam jumlah banyak dan berperan membantu proses fotosintesis, yaitu pembentukan senyawa organik baru yang diangkut ke organ tempat penimbunan, yaitu umbi, sekaligus memperbaiki kualitasnya (Samadi dan Cahyono, 2005).

$$
\text { Pada dosis } 30 \mathrm{ml} / \mathrm{tanaman}
$$

menyebabkan jumlah umbi menurun, diduga karena $\mathrm{pH}$ semakin masam, sehingga kekurangan unsur $\mathrm{P}$, tetapi diameternya meningkat, diduga unsur $\mathrm{K}$ yang digunakan untuk pembesaran umbi lebih terpenuhi. Unsur hara fosfor $(\mathrm{P})$ bagi tanaman berguna untuk merangsang pertumbuhan akar dan membentuk sistem perakaran yang baik dan menggiatkan pertumbuhan jaringan tanaman yang membentuk titik tumbuh tanaman (Rina, 2019).

Pada variabel pengamatan berat umbi perlakuan pupuk kandang kotoran sapi dosis 10 dan 20 t/ha dengan penambahan peningkatan dosis PGPR akar bambu tidak meningkatkan berat umbi, hal ini diduga karena pada dosis pupuk kandang tersebut tidak dapat memperbaiki $\mathrm{pH}$ tanah. Sedangkan pada perlakuan pupuk kandang kotoran sapi dosis 30 t/ha dengan penambahan peningakatan dosis PGPR akar bambu sampai dosis $30 \mathrm{ml} /$ tanaman mampu meningkatkan berat umbi, hal ini diduga karena pada dosis pupuk kandang tersebut mampu memperbaiki pH. Sejalan dengan penelitian Wahyuningsih, et. al., (2017) menyatakan bahwa produksi tanaman bawang merah pada perlakuan dosis $30 \mathrm{ml}$
PGPR dan 20 t/ha pupuk kotoran kelinci lebih tinggi dibanding perlakuan tanpa PGPR dan pupuk kotoran kelinci.

\section{Pupuk kandang kotoran sapi}

Berdasarkan hasil analisis ragam menujukkan bahwa perlakuan tunggal pupuk kandang kotoran sapi berpengaruh terhadap tinggi tanaman umur 23 dan 33 HST, tetapi tidak berpengaruh pada umur 43 HST, jumlah daun, jumlah umbi, diameter umbi dan berat umbi. Pada variabel pengamatan tinggi tanaman perlakuan pupuk kandang kotoran sapi berpengaruh pada umur 23 dan 33 HST, namun pada umur 43 HST tidak berpengaruh. Hal ini diduga pada umur 43 HST perlakuan pemberian pupuk kandang kotoran sapi dosis 10 t/ha sudah terdekomposisi, sementara dosis $20 \mathrm{t} / \mathrm{ha}$ dan $30 \mathrm{t} / \mathrm{ha}$ belum terdekomposisi dengan sempurna, sehingga menyebabkan tinggi tanaman dengan pemberian dosis $10 \mathrm{t} / \mathrm{ha}$ tak berbeda dengan perlakuan dosis $20 \mathrm{t} / \mathrm{ha}$ dan $30 \mathrm{t} / \mathrm{ha}$.

Pada variabel pengamatan jumlah daun, jumlah umbi dan berat umbi, perlakuan pupuk kandang kotoran sapi tidak berpengaruh, diduga pupuk kandang kotoran sapi belum terdekomposisi dengan sempurna. Pupuk kandang kotoran sapi memiliki kandungan serat yang tinggi. Serat atau selulosa merupakan senyawa rantai karbon yang akan mengalami proses dekomposisi lebih lanjut. Proses dekomposisi senyawa tersebut memerlukan unsur $\mathrm{N}$ yang terdapat dalam kotoran, sehingga kotoran sapi tidak dianjurkan untuk diaplikasikan dalam bentuk segar, perlu pematangan atau pengomposan terlebih dahulu. Apabila pupuk diaplikasikan tanpa pengomposan, akan terjadi perebutan unsur $\mathrm{N}$ antara tanaman dengan proses dekomposisi kotoran (Risnandar, 2018).

Bahan organik merupakan sumber $\mathrm{N}$ utama di dalam tanah dan berperan cukup besar dalam proses perbaikan sifat fisika, kimia dan biologi tanah (Sudaryono, 2009). $\mathrm{N}$ berfungsi untuk menyusun asam amino (protein), asam nukleat, nukleotida dan klorofil pada tanaman, sehingga membuat 
tanaman lebih hijau, mempercepat pertumbuhan tanaman (tinggi, jumlah anakan, jumlah cabang dan menambah protein hasil panen (Rina, 2019).

Pada variabel pengamatan jumlah daun perlakuan peningkatan dosis pupuk kandang sampai 20 t/ha mampu meningkatkan jumlah daun, tetapi peningkatan selanjutnya yaitu $30 \mathrm{t} / \mathrm{ha}$ justru menyebabkan penurunan jumlah daun, hal ini diduga karena pada dosis 30 t/ha belum terdekomposisi dengan sempurna.

Pada variabel pengamatan jumlah umbi dan berat umbi pada perlakuan dosis $30 \mathrm{t} / \mathrm{ha}$ pupuk kandang kotoran sapi mampu meningkatkan jumlah umbi dan berat umbi, hal ini diduga pada dosis tersebut dapat memperbaiki $\mathrm{pH}$, sehingga unsur $\mathrm{P}$ tersedia unuk tanaman. Unsur hara fosfor $(\mathrm{P})$ bagi tanaman berguna untuk merangsang pertumbuhan akar dan membentuk sistem perakaran yang baik dan menggiatkan pertumbuhan jaringan tanaman yang membentuk titik tumbuh tanaman (Rina, 2019). Jika tanaman kekurangan unsur $P$, sistem perakarannya tidak dapat berkembang secara sempurna. Akibatnya, tanaman tumbuh lambat, ujung daunnya yang lebih tua menguning dan menjalar pada daun diatasnya, sehingga umbi yang dihasikannya pun kecil-kecil (Samadi dan Cahyono, 2005).

Pada variabel diameter umbi semakin tinggi dosis pupuk kandang menyebkan diameter umbi semakin kecil, hal ini diduga karena tanaman kekurangan unsur K. Kalium merupakan unsur ketiga setelah $\mathrm{N}$ dan $\mathrm{P}$ yang dibutuhkan tanaman dalam jumlah banyak dan berperan membantu proses fotosintesis, yaitu pembentukan senyawa organik baru yang diangkut ke organ tempat penimbunan, yaitu umbi, sekaligus memperbaiki kualitasnya. Tanaman yang kekurangan unsur K mulamula akan timbul bercak berwarna coklat pada ujung daun, kemudian menjalar ke pangkal yang akhirnya layu dan tanaman akan mati (Samadi dan Cahyono, 2005).

\section{PGPR akar bambu}

Berdasarkan hasil analisis ragam menunjukkan bahwa perlakuan tunggal
PGPR akar bambu tidak berpengaruh terhadap semua variabel pengamatan. $\mathrm{pH}$ tanah masan dan dengan penambahan PGPR yang masam membuat tanah semakin masam, diduga karena $\mathrm{pH}$ tanah yang masam sehingga unsur hara $\mathrm{P}$ tidak tersedia. $\mathrm{pH}$ tanah dapat mempengaruhi ketersediaan hara tanah dan bisa menjadi faktor yang berhubungan dengan kualitas tanah. $\mathrm{pH}$ sangat penting dalam menentukan aktivitas dan dominasi mikroorganisme tanah yang berhubungan dengan proses-proses yang sangat erat kaitannya dengan siklus hara (Sudaryono, 2009).

PGPR (Plant Prowth Promoting Rhizobacteria) atau dalam bahasa Indonesia berarti bakteri perakaran pemacu pertumbuhan tanaman (BP3T) adalah bakteri yang terdapat di sekitar perakaran rumpun bambu dimana terdapat eksudat yang dikeluarkan akar sebagai nutrisi bagi mikroba. PGPR mengandung bakteri Pseudomonas flourenscens dan Bacillus polymixa yang mampu memacu pertumbuhan tanaman melalui beberapa cara, yaitu : merombak dan mengurai bahan organik menjadi nutrisi tanaman, mengeluarkan cairan yang mampu melarutkan mineral phosphate menjadi unsur hara, mengeluarkan enzim pemacu pertumbuhan tanaman, mengeluarkan antibiotik dan menekan mikroba patogen serta membantu menangkap dan mengumpulkan nitrogen $(\mathrm{N})$ dari udara, selanjutnya diubah menjadi unsur yang siap diserap tanaman (Yuliandri, 2017). Kebanyakan bakteri mempunyai $\mathrm{pH}$ optimum untuk pertumbuhan, yaitu $\mathrm{pH}$ 6,57,5. Pada $\mathrm{pH}$ dibawah 5 dan di atas 8,5 , bakteri tidak dapat tumbuh dengan baik (Waluyo, 2007 dalam Jannah, 2016).

\section{KESIMPULAN}

Berdasarkan hasil penelitian maka dapat diambil kesimpulan (i) tidak terdapat pengaruh interaksi antara perlakuan kombinasi pupuk kandang kotoran sapi dan PGPR akar bambu terhadap pertumbuhan dan hasil tanaman bawang merah, (ii) 
Pemberian pupuk kandang kotoran sapi berpengaruh terhadap tinggi tanaman 23 dan 33 HST, namun tidak berpengaruh terhadap tinggi tanaman umur 43 HST, jumlah daun, jumlah umbi, diameter umbi dan berat umbi, (iii) penambahan PGPR akar bambu tidak memberikan pengaruh terhadap tinggi tanaman, jumlah daun, jumlah umbi, diameter umbi dan berat umbi, (iv) tidak terdapat interaksi terbaik antara pupuk kandang kotoran sapi dan PGPR akar bambu terhadap tinggi tanaman, jumlah daun, jumlah umbi, diameter umbi dan berat umbi, (v) didapatkan dosis terbaik penggunaan pupuk kandang kotoran sapi terhadap fase vegetatif bawang merah yaitu pada perlakuan $\mathrm{p}_{2}$ (20 t/ha), (vi) tidak didapatkan dosis terbaik penggunaan PGPR akar bambu.

\section{UCAPAN TERIMAKASIH}

Ucapan terimakasih kepada LPPM Sekolah Tinggi Ilmu Pertanian Amuntai atas pembiayaan penelitian ini melalui Hibah Penelitian Tahun 2019 dengan kontrak Nomor : 06/LPPM-STIPER AMT/KP/VI/ 2019 tanggal 15 Juni 2019.

\section{DAFTAR PUSTAKA}

BPS Kabupaten Tabalong. (2018). Luas Panen dan Produksi Sayur-Sayuran 2010-2017. https://tabalongkab.bps. go.id/statistictable/2015/12/28/1390/lu as panen -dan produksi sayur-sayuran2010-2017.html. Diakses pada tanggal 10 November 2018.

Harianti, M., Herviyanti \& Hermansah. (2004). Tingkat Keracunan Besi dalam Bentuk Ferro dan Ferri serta Pertumbuhan Tanaman Padi (Oryza sativa L.) pada Media Pasir. Jurnal Solum, 1(2), 74-83. https://doi.org/ 10.25077/js.1.2.74-83.2004.

Jannah, R. (2016). Pengaruh bakteri Bacillus Cereus dan Psedudomons Aaeruginosa terhadap Produktivitas Tanaman Padi yang Terinfeksi Penyakit Blass sebagai Referensi Mata Kuliah Mikrobiologi. Skripsi. Fakultas
Tarbiyah dan Keguruan. Program Studi Pendidikan Biologi.

Januarti, R. A., Zulkifli, L \& Sedijani, P. (2016). Pengaruh penambahan kotoran kelinci pada media tanah terhadap pertumbuhan tanaman sawi (Brassica juncea) sebagai pengayaan praktikum fisiologi tumbuhan. Jurnal. Universitas Mataram. Fakultas Keguruan dan Ilmu Pendidikan Program Studi Pendidikan Biologi.

Kaderi, H. (2015). Sidik Cepat Keracunan Unsur Fe, Mn dan Al Pada Tanaman di Lahan Rawa Sulfat Masam. Balittra. http://balittra.litbang.go.id/. Diakses pada tanggal 26 Juli 2019.

Lasmiati, H. (2013). Petani Kembangkan Bawang Merah. http://kalsel.antara news. com. Di akses pada tanggal 27 November 2018.

Nugraha, Y dan Rumanti, I. P. (2017). Perakitan Padi Toleran Keracunan Besi. Iptek Tanaman Pangan, 12(1), 9-24. http://pangan.litbang.pertanian. go.id/files/02-IPTEK12-01-2017.

Prasojo, M. (2018). Penanggulangan Keracunan Besi (Fe) pada Sawah Bukaan Baru. https:/unsurtani.com/ 2018/07/ penganggulangan-keracunan -besi-fe-pada-sawah-bukaan-baru. Diakses pada tanggal 25 Juli 2019.

Rina, D. (2019). Manfaat Unsur Hara N, P dan $\mathrm{K}$ Bagi Tanaman. http://kaltim.litbang. pertanian.go.id/. Diakses tanggal 15 Juli 2019.

Risnandar, C. (2018). Jenis dan Karakteristik Pupuk Kandang. https://alamtani.com/ pupukkandang/amp/. Di akses pada tanggal 13 November 2018.

Samadi, B. dan Cahyono, B. (2005). Bawang Merah. Kanisius.Yogyakarta.

Sejati, H. K., Astiningrum, M dan Tujiyanta. 2017. Pengaruh macam pupuk Kandang dan konsentrasi Pseudomonas fluorescens pada hasil Tanaman bawang merah (Allium cepa 
Mahdiannoor, Murjani \& Isma, Pertumbuhan dan hasil tanaman bawang merah...

fa. Ascalonicum, L.) Varietas Crok Kuning. VIGOR: Jurnal Ilmu Pertanian Tropika dan Subtropika 2(2), 55-59. DOI: 10.31002/vigor. $\mathrm{v} 2 \mathrm{i} 2.489$.

Sudaryono. (2009). Tingkat Kesuburan Tanah Ultisol pada Lahan Pertambangan Batubara Sangatta, Kalimantan Timur. Jurnal Teknologi Lingkungan, 10 (3), 337-346. DOI: https://doi.org/10.29122/jtl.v10i3.1480

Sutedjo, M. M. (2008). Pupuk dan Cara Pemupukan. Rineka Cipta. Jakarta.

Tim Bina Karya Tani. (2008). Pedoman Bertanam Bawang Merah. Yrama Widya. Bandung.
Wahyuningsih, E. N., Herlina dan Tyasmoro, S. Y. (2017). Pengaruh Pemberian PGPR (Plant Growth Promoting Rhizobacteria) dan Pupuk Kotoran Kelinci terhadap Pertumbuhan dan Hasil Tanaman Bawang Merah (Allium ascalonicum L.). Jurnal Produksi Tanaman, 5(4), 591-599. http://protan.studentjournal. ub.ac.id.

Yuliandri, L. A. (2017). Pertanian Maju Masyarakat Sejahtera: PGPR (Plant Growth Promoting Rhizobacter). http://liliadamyuliandri1984.blogspot. com/. Di akses pada tanggal 10 November 2018. 